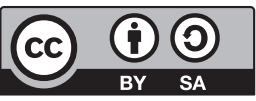

DOI 10.31261/IJREL.2019.5.2.02

\title{
Tetiana Simonenko
}

Ukraine (ORCID: 0000-0001-5963-0451)

\section{Yulia Nikitska}

Ukraine (ORCID: 0000-0002-0482-8011)

\section{The Technology of Development of Transversal Skills of Future Philologists in the Process of Distance Learning in the Online Course "Effective Communication"}

\begin{abstract}
The article is devoted to an important problem in the higher educational system, namely, the presentation of the technology of development of transversal skills of future philologists in the process of distance learning in the online course "Effective Communication." This study presents experimental information that makes it possible to determine the effectiveness of the proposed technology for the development of such transversal skills in students as: critical thinking, interpersonal skills, organisational skills, and informational skills.

K e y w o r d s: higher education, transversal skills, online course "Effective Communication", future philologists, distance learning
\end{abstract}

\section{Introduction}

The world in which we live has changed a lot over the last time. What has affected the change in the world around us? First of all, the catalyst for the transformation of the world at the moment is modern digital technology. Such a conclusion was 
made in 2017 at the World Economic Forum. A modern educational system must take into account all these processes of change and transformation of the world. And in this regard, in establishments of higher education, we must rebuild the educational system as much as possible in order to meet the needs of the individual, and to provide such knowledge and skills so that the modern student can be useful for the world and can fully live in the transforming world. What skills can help individuals to find themselves in the world of digital technology and globalisation processes? We believe that these may be transversal skills. In our opinion, all participants in the educational process, teachers and students of different specialties and different training programmes should have transversal competence. We are convinced that today's humanists who have transversal competences are able to make very interesting accents in the economy of the world as a whole, as well as in the development of human spiritual and cultural values.

In our research, we are focusing on a graduate student. At this stage, it is necessary to integrate the science and practice of learning as much as possible, to make it possible for modern students to master the technologies of professional activity. Graduates of master's programmes should have versatile professional competencies that are based on the principles of fundamental, systematic, scientific, perspective connection with life. Students must have qualities that will enable them to perform both individual and collective tasks; they must be ready for self-education. A competence-based approach, which is determined as a result not only of higher education, but also of life - long-term learning ("Council Recommendation on Key Competences for Lifelong Learning...," 2018) - ensures clarity and comparability of learning results, acquired competencies and qualifications, and creates a solid foundation for European and world integration. Work with the online course "Effective Communication" provides future philologists with transversal skills. In the first part of this article, we present the transversal skills that future philologists acquire in the process of learning from e-course materials and how distance learning can be used for their development. In the second part, we analyse the results of research conducted from September 2017 to January 2019, showing the use of the technology of work with the online course "Effective Communication." We have represented a set of activities and elements of analysis of surveys conducted with students who have completed this distance learning module in the online course at Bohdan Khmelnytsky National University at Cherkasy at the Institute of Social Communications. The purpose of this study is to present the technology of development of transversal skills of future philologists in the process of working with the online course that is aimed at increasing the professional competitive ability of the personality and facilitates transformation into a new role. This may be the role of a consultant, a mentor, a public figure, a successful manager, a customer service specialist, or an administrator. 


\section{Transversal Skills of a Specialist as a Guarantee of Success on the Job Market}

What is at the heart of the design and implementation of the educational programme is the competence model of the expert (we are interested in the profile - philology).

Today, it is generally accepted that competence is divided into two groups: subject specific competences and key competences (generic competences, transferable skills, soft competences, transversal competencies) that are universal, not tied to the subject area, but must be balanced with special competences when developing educational programmes and their formation must necessarily be planned. It should be noted that scholars are ambiguous about terms, but we adhere to the term that UNESCO proposed for general use in 2015, namely transversal competencies. Transversal competences provide a "transfer of learning," that is, the transfer of acquired knowledge, skills, and meta-cognitive abilities of the individual to solve situations of real life.

The philology programme focuses on the formation of transversal competences as one of the key competences. The presence of transversal competence enables the individual to feel comfortable in a changing world, in an infinite stream of information and transformation of text content. Transversal competence as a group of skills is now a priority in many countries. In particular, the importance of its development is emphasised in training programmes in the USA. This group includes the following most important skills:

- interpersonal skills;

- critical and innovative thinking;

- intrapersonal skills;

- partnership, global citizenship.

Beginning in 2015, the foundation for the development of such skills was laid in the curricula of the training course of philology, namely:

- find and evaluate information,

- memorise information,

- manage time,

- use electronic tools for work,

- summarise.

In 2017, all these process skills were combined under the term "soft skills." At present, the development of such skills is aimed at the entire training system in various progressive countries: the USA, Belgium, Australia, Germany. In Ukraine, training programmes for the development of skills are also changing. But we are interested in not just "soft skills," we are interested in transversal skills. 
What do we mean by the group of transversal skills in the process of implementing the technology of training of future philologists and - in particular - in the process of distance learning in the online course "Effective Communication"?

First of all, we need to clearly identify the foundation: what will we form and develop in students? We are interested in several vectors in this aspect:

- information competence,

- learning competence,

- partnership competence,

- communicative competence.

\section{Distance Learning as an Effective Form of the Development of Students' Transversal Skills}

In the philology curriculum there is a place where one can organise work and develop transversal skills. The traditional approach to organisation of education and using establishment of higher education audiences - and only these audiences to master transversal skills is neither the only nor the best option. In fact, work on these skills requires a lot of time, individual and teamwork, personalisation, equipment, which is why a different structure is required for work: e-learning in combination with distance learning. Inside the learning management system, students are placed in a semi-managed environment where restrictions may be more free than in a university classroom. With the help of distance learning and working with the online course "Effective Communication," one can erase three restrictions on the audience: time, content, and the degree of personalisation. All these elements are completely interconnected. More time allows one to perform more complex tasks and perform larger or more complex content. For example, in order to develop techniques of a negotiation process, the future philologist must conduct systematisation, analysis, synthesis, which requires much more time than what is limited in terms of training a specific audience and is tied to study time. More time also gives more autonomy when dealing with complex content and choosing tools to solve problems. If we take the example of "using information," depending on the complexity, at the beginning it can take a lot of time if students lack information technology. The interest of the time is to keep them autonomous, one-on-one from the task, and allow them to experiment in various ways to search for information and use it constructively and effectively. In this case, distance learning significantly improves the quality of the product, since the student the future philologist - is not afraid to cope with the task for a certain time. The student does not feel the time limit of his/her search. Having more time also allows 
students to confront more difficult problems and make them more interesting. The use of distance learning in the process of working with the online course "Effective Communication" forces students to make the most of information and communication technologies. But here we need to take into account one important aspect. If we are talking about the autonomy of work, then we need to consider working together, because it is also very important: the student also has time management in distance learning, that is, the time for working with information and performing the task is limited. Deadlines require a certain result; in our case, it is a specific product, for example, the description of the experiment conducted on one of the topics related to public speaking and techniques of belief.

\section{Experience in the Development of Transversal Skills of Future Philologists in Distance Learning Technology for the Online Course "Effective Communication"}

In 2016, Bohdan Khmelnytsky National University at Cherkasy recruited students for the master's programme of philology. Accordingly, it was necessary to create a specific programme in order to develop both professional competencies of students and transversal skills. But within 1.5 years of the master's programme it is impossible to give students all the necessary elements, so independence in learning, the use of distance learning with specific professionally oriented courses, namely, the online course "Effective Communication" has a key impact on their studies and gives a corresponding quality result. Thus, the student - the future philologist - must form the skills to independently look for the needed elements. However, a student must be critical of what he/she finds, and then combine found information with one already known to solve the problem. That was the purpose of teaching students in the online course "Effective Communication." The distance online course training was packaged into a training module. It consisted of 7 activity groups for the first year of study and 5 blocks of tasks for the second year (the master's programme lasts 1.5 years in Ukraine).

As we wrote above, we developed an independent module for the first year of study for the master's programme focusing on such course content. The content was presented in the form of 7 groups. Each group, in turn, had tasks of different levels of complexity:

- art of persuasion,

- interpersonal communication techniques,

- effective oral speech,

- public performance, 
- active listening,

- constructive feedback,

- conducting conversations and negotiations.

The experiment was attended by 58 students of the philology master's programme in the first year of study, and 39 students in the second year of study. The number of second year students was lower for certain subjective reasons: some students did not continue their studies in the programme, some switched to other programmes. In the first year of study, we identified two groups: experimental and control. We conducted the experiment in one university - Cherkasy National University named after B. Khmelnitsky with philology students (Ukrainian / English philology). Students were given about 10-14 days to complete each group of tasks. The content was with a progressive level of complexity, and it was not coordinated at all with the classes that they received during the classroom work: the module was completely independent. The observed activity period - for which we will present some results and comments here - was from September 2017 to January 2019. The main transversal skills that we focused on were:

- critical thinking skills;

- architecture of oral and written text (communicative skills);

- interpersonal skills (partnership), organisational skills (time management, resource management);

- skills of working with information.

\section{Experimental Results}

\section{Researchers' Evaluation of the Use of Transversal Skills during the Training Module for the Online Course "Effective Communication"}

Table 1 below presents our skills needs assessment for the first year of the master's programme. We gave tasks to students who were focused on the development of transversal skills; in particular, the priority was effective text as a product of activity. One of the transversal skills is the ability to speak effectively, so the technique was aimed at developing a rhetorical way of speaking, including speech literacy, effective oral speech. In the process of learning, we offered students tasks for editing text, that is, editing problematic grammatical constructions in the Ukrainian language. This contributed to the development of students's speech culture. We offered tasks for the formation of skills to find the right answer, to distinguish the correct options from incorrect ones. For example (further Ukrainian): приймати участь - брати участь; вірно говорити - правильно говорити; у повній мірі - повною мірою, слідуюча зупинка - наступна зупинка. There were also proposed tasks for the construction and edition of texts. At first, the texts were not 
high enough, as the students were beginners. Of course, these numbers are quite subjective, but they must show the importance attached to each skill. In Table 1 it can be seen that in the process of distance learning we attached a lot of attention to the quality of the text, many tasks were focused on transfiguration, addition, reduction, editing, analysis of problematic communicative situations. At the beginning of the work - the first six months of the distance learning framework - we paid less attention to time management, since the proposed activities initially required less time to perform. In the first year, from 1 to 14 lessons were grouped around the topic of speaking and negotiating skills. Some of the exercises were with spaces that needed to be filled in with vocabulary, some required short written answers, and others - multiple-choice questions. Of course, there were tasks that required students' creativity. The types of documents on which the actions were based were varied: images, texts, Internet links to websites, videos. This was done in order to answer required different search methods. In order to develop critical judgment, provocation assignments with prescribed incorrect answers were added, specifically designed to mislead the student. For example, in the exercise on the formation of skills to negotiate provocations of a substantive nature were envisaged on the topic of teaching conflict resolution arising in connection with different opinions and interests. By the way, not all students who were involved in the experiment were critical of the text and were able to identify meaningful errors. Thus, there was no reaction to provocation. This gave us the opportunity to see gaps in knowledge and skills, and to improve the blocks of tasks in the process of experimental work.

Table 1.

Work on the development of transversal skills in the first year of master's programme (scale from 1 - "never" to 4 - "very often")

Transversal skills

\begin{tabular}{lccccc} 
Basics of activities & $\begin{array}{c}\text { Organisational } \\
\text { (time } \\
\text { management) }\end{array}$ & $\begin{array}{c}\text { Critical } \\
\text { thinking }\end{array}$ & $\begin{array}{c}\text { Interactivity } \\
\text { (partnership) }\end{array}$ & $\begin{array}{c}\text { Information } \\
\text { skills }\end{array}$ & $\begin{array}{c}\text { Text } \\
\text { architecture }\end{array}$ \\
\hline $\begin{array}{l}\text { Art of persuasion } \\
\text { Interpersonal commu- }\end{array}$ & 2 & 4 & 4 & 4 & 4 \\
nication techniques & 2 & 4 & 3 & 4 & 3 \\
Effective oral speech & 2 & 3 & 3 & 3 & 4 \\
Public performance & 2 & 4 & 2 & 4 & 3 \\
Active listening & 3 & 3 & 4 & 3 & 4 \\
Constructive feedback & 3 & 4 & 2 & 3 & 4 \\
Conducting conversa- & 3 & 4 & 3 & 4 & 3 \\
tions and negotiations & 2.4 & 3.7 & 3 & 3.5 & 3.5 \\
\hline Average & & & & & \\
\hline
\end{tabular}

S our ce: Own work. 
During the second year, students could give more complex written answers, so the requirements for the text architecture were increased. The work on critical judgment was considered already completed mainly during the first year, but sometimes provocative tasks were still used. We paid more attention to time management, as the complexity of the tasks increased; it was interesting to analyse what time management could be in terms of distance learning, whether the assigned tasks would be fulfilled and whether the majority of students would have problems with deadlines. Also, in the process of implementing the distance learning technology for the proposed independent module, certain groups of tasks on the experimental texts were effective in developing interactive skills and skills in working with information (Table 2).

Table 2.

Presentation of work on the development of transversal skills in the second year of master's programme (scale from 1 - "never" to 4 - "very often")

\begin{tabular}{lccccc}
\hline $\begin{array}{c}\text { Task name: } \\
\text { effective text } \\
\text { analysis }\end{array}$ & $\begin{array}{c}\text { Organisational } \\
\text { skills }\end{array}$ & $\begin{array}{c}\text { Critical } \\
\text { thinking }\end{array}$ & $\begin{array}{c}\text { Transversal skills } \\
\text { Interactivity } \\
\text { (partnership) }\end{array}$ & $\begin{array}{c}\text { Working with } \\
\text { information }\end{array}$ & $\begin{array}{c}\text { Text } \\
\text { architecture }\end{array}$ \\
\hline Text 1 & 4 & 2 & 4 & 4 & 4 \\
Text 2 & 4 & 3 & 4 & 4 & 4 \\
Text 3 & 4 & 2 & 4 & 4 & 4 \\
Text 4 & 4 & 2 & 4 & 4 & 3 \\
Text 5 & 4 & 4 & 3 & 4 & 4 \\
\hline Average & 4.0 & 2.6 & 3.8 & 4 & 3.8 \\
\hline
\end{tabular}

S our c e: Own work.

\section{Students' Evaluation of the Technology of Transversal Skills Formation during the Work with the Distance Online Course "Effective Communication"}

At the end of each year, an anonymous survey questionnaire was sent to students. Among the questions was a question on the Rensys Likert scale about their attitude to the level of transversal skills. Tables 3 and 4 below summarise the results for the covered period (the period of study of the master's programme from September 2017 to January 2019). This is based on certain opinions of students, and these results are subjective, but they reflect the relationships that students had. Therefore, since the factor of subjectivity is taken into account, it is correct to speak not of results, but of assumptions. During the first year (Table 3), we can see that how the "Effective Communication" module helped them in structuring the text; the students felt that it was enough for them to help them develop transversal skills. We did not hope to get such a result because the students were just beginners. But still, most of them felt the progress by working on tasks for such technology. Fewer students felt the outcome regarding the formation of critical thinking. This may be because they had not seen the provocations; they had not yet had enough 
competence to perform this or that task. The table also shows the attitude to the two other positions: the information block and the organisational block of tasks that were focused on the formation of transversal skills. Fever students defined their interactive skills and partnership skills. We also asked the students which of the course assignments were interesting for them, which were difficult, which assignments might have been superfluous. Most students were very positive about the programme of this module. The most interesting tasks, in their opinion, were tasks for the development of a culture of speech (communicative and interactive competence), as well as tasks for the development of critical thinking.

Table 3.

The importance of the online course "Effective Communication" module in the development of transversal skills among students: 1st year of study (from 1 to 4) $n=58$

\begin{tabular}{lccccc}
\hline \multicolumn{1}{c}{ Skills } & 1 & 2 & 3 & 4 & Average \\
\hline Text architecture & 2 & 2 & 26 & 28 & 3.4 \\
Working with information & 2 & 4 & 13 & 39 & 3.5 \\
Critical thinking & 6 & 11 & 22 & 19 & 2.9 \\
Organisational skills & 13 & 20 & 17 & 8 & 2.3 \\
Interactivity (partnership) & 8 & 14 & 29 & 7 & 2.6 \\
\hline
\end{tabular}

S o u r c e: Own work.

In the second year of study, students felt more progress in the formation of transversal skills thanks to the work with the architecture of texts. Also, the indicators changed with respect to critical thinking and organisational skills (time management). The second year of study on the proposed technology and the results of student surveys provide an opportunity to state the correctness of the selected methods and techniques of teaching, as well as the organisation of training.

Table 4.

The importance of the online course "Effective Communication" module in the development of transversal skills among students: $2^{\text {nd }}$ year of study (from 1 to 4 ) $n=39$

\begin{tabular}{lllllc}
\hline \multicolumn{1}{c}{ Skills } & 1 & 2 & 3 & 4 & Average \\
\hline Text architecture & 2 & 4 & 7 & 26 & 3.4 \\
Working with information & 4 & 5 & 9 & 21 & 3.2 \\
Critical thinking & 3 & 5 & 6 & 24 & 3.2 \\
Organisational skills & 6 & 8 & 7 & 18 & 2.9 \\
Interactivity (partnership) & 2 & 5 & 4 & 28 & 3.4 \\
\hline
\end{tabular}

S o u r e: Own work. 
Above in the text, we wrote that the experiment involved students in the amount of 58 (the first year of studies), and 39 the second year of study of the master's programme. It was allocated experimental and control group. The results of the study also showed that the students of the experimental group and their competence were better than the transversal skills of the students of the control group. In general, we stated that the level of transversal skills of students of the experimental group after passing the independent module "Effective Communication" in remote form increased by $16 \%$. This is what gives us the confidence to think about the right course content, and its usefulness and effectiveness.

\section{Conclusion}

The above results encourage us to think that the online course "Effective Communication" module was useful and really helped students to develop transversal skills. Transversal skills of philology students will be used after graduating from the master's programme not only for studying linguistics, but also for the other fields of activity, if circumstances develop for the transformation of the professional sphere. We believe that transversal skills will enable students to be more confident in the changing and transforming world of digital technology, to be more in demand on the labour market, and thus to be more successful. We believe that to achieve these goals, the technology of distance learning is effective and constructive. And this is confirmed by the results of experimental work.

\section{References}

Digital competence (2017). Retrieved from http://europass.cedefop.europa.eu/resources/digital -competencies (accessed 20 July 2018).

Digital Transformation Initiative Telecommunications Industry World Economic Forum (2017). Retrieved from http://reports.weforum.org/digital-transformation/wpcontent/blogs.dir/94/mp /files/pages/files/dti-telecommunications-industry-white-paper.pdf (accessed 20 July 2018).

Europe 2020 strategy (2015). Retrieved from https://ec.europa.eu/digital-single-market/en/europe -2020-strategy (accessed 20 July 2018).

Education and Training 2020 Work programme Thematic Working Group "Assessment of Key Competences" Literature review, Glossary and examples (2012). European Commission, Directorate-General for Education and Culture, November, 52.

European e-Competence Frame work 3.0 (EN) (2014). Retrieved from http://www.ecompetences .eu/wp-content/uploads/2014/02/European-e-Competence-Framework-3.0_CEN_CWA_16234 -1_2014.pdf (accessed 20 July 2018). 
The International Society for Technology in Education (ISTE) (2016). Retrieved from http://www .iste.org/standards/standards (accessed 20 July 2018).

Saran, C. (2011). IT and marketing: working together for business success. Retrieved from https:// www.computerweekly.com/feature/IT-and-marketing-working-together-for-business-success (accessed 9 August 2011).

Smyrnova-Trybulska, E., Morze, N., \& Kuzminska, O. (2018). Academic information transparency: from teachers' e-portfolio to upgrading the rankings of universities. In: DIVAI 2018: Štúrovo, Slovakia, May 2-4, 2018: Conference proceedings. Prague: Wolters Kluwer: 347-356.

White, M. G. (2018). How Is Information Technology Used in Marketing Careers? Retrieved from https://jobs.lovetoknow.com/how-is-information-technology-used-marketing-careers (accessed 22 May 2018).

Tetiana Simonenko, Yulia Nikitska

\title{
Technologia w rozwijaniu kompetencji przekrojowych u przyszlych filologów w procesie uczenia się na odległość z wykorzystaniem kursu online „Efektywna komunikacja”
}

\author{
Streszczenie
}

Artykuł poświęcono istotnemu problemowi systemu szkolnictwa wyższego, jakim jest wykorzystanie technologii rozwoju kompetencji przekrojowych u przyszłych filologów w procesie uczenia się na odległość za pomocą kursu online „Efektywna komunikacja”. Przedstawione badanie prezentuje informacje, które umożliwiają określenie efektywności zaproponowanej technologii w rozwijaniu u studentów takich kompetencji przekrojowych, jak: krytyczne myślenie, kompetencje interpersonalne oraz kompetencje w posługiwaniu się technologią informacyjną.

S łow a kluc zowe: kształcenie wyższe, kompetencje przekrojowe, kurs online „Efektywna komunikacja", przyszli filologowie, nauczanie na odległość

Tetiana Simonenko, Yulia Nikitska

\section{Технология развития трансверсальных навыков будущих филологов в процессе дистанционного обучения в онлайн-курсе «Эффективная коммуникация»}

\begin{abstract}
А н но о а ци я
Статья посвящена актуальной проблеме в системе высшего образования, а именно презентации технологии развития трансверсальных навыков будущих филологов в процессе дистанционного обучения в онлайн-курсе «Эффективная коммуникация». В научном исследовании представлена экспериментальная информация, которая позволяет определить эффективность предлагаемой технологии для развития таких сквозных навыков учащихся, как критическое мышление, навыки межличностного общения, организационные навыки и информационные навыки.
\end{abstract}


К л ю ч е в ы е с л о в а: высшее образование, трансверсальные навыки, онлайн-курс «Эффективная коммуникация», будущие филологи, дистанционное обучение

Tetiana Simonenko, Yulia Nikitska

\title{
La tecnología de desarrollo de habilidades transversales de futuros filólogos en el proceso de aprendizaje a distancia en el curso en línea „Comunicación efectiva“"
}

\author{
Resumen
}

El artículo está dedicado al problema real en el sistema de educación superior, a saber, la presentación de la tecnología de desarrollo de habilidades transversales de futuros filólogos en el proceso de aprendizaje a distancia en el curso en línea "Comunicación efectiva". El estudio científico presenta información experimental que permite determinar la efectividad de la tecnología propuesta para el desarrollo de las habilidades transversales de dichos estudiantes, tales como: pensamiento crítico, habilidades interpersonales, habilidades organizativas y habilidades informativas.

P a labras c lave: educación superior, habilidades transversales, curso en línea "Comunicación efectiva", futuros filólogos, educación a distancia 